\title{
Aclidinium bromide inhibits the growth and metastasis of gastric cancer MKN-28 cells via the PI3K signaling pathway
}

\author{
YUANZHI WANG ${ }^{1}$, PING CUI $^{2}$, JINGJING LIU ${ }^{3}$, HONGXIA WU $^{4}$ and JUN MA ${ }^{5}$ \\ ${ }^{1}$ Department of Operating, Binzhou Central Hospital; ${ }^{2}$ Department of Oncology, \\ Binzhou City TB Prevention and Control of Hospital; Departments of ${ }^{3}$ Neurosurgery and ${ }^{4}$ Nursing, \\ Binzhou Central Hospital; ${ }^{5}$ Department of Infectious Diseases, Binzhou City TB Prevention \\ and Control of Hospital, Binzhou, Shandong 251700, P.R. China
}

Received December 5, 2017; Accepted May 5, 2018

DOI: $10.3892 / \mathrm{mmr} .2018 .9220$

\begin{abstract}
The present study investigated the effect and underling mechanisms of aclidinium bromide, a novel, inhaled long-acting muscarinic antagonist, on the development of gastric cancer. Human gastric cancer MKN-28 cells, as a model in vitro, were treated with aclidinium bromide and dimethyl sulfoxide. Cell Counting Kit-8 assay, transwell assay and flow cytometry were used to assess cell proliferation, invasion/migration and apoptosis, respectively. In addition, western blotting was performed to determine the relative expression of proteins associated with apoptosis and the phosphatidylinositol-3-kinase (PI3K) signaling pathway. Optical density values of MKN-28 cells were decreased in a time- and dose-dependent manner in the aclidinium bromide treated group. Matrigel invasion analysis demonstrated the number of invasive cells were significantly decreased in the aclidinium bromide-treated group when compared with the control group. Furthermore, aclidinium bromide led to the marked reduction of the number of MKN-28 cells passing though the microwells of the transwell chamber. The expression levels of the anti-apoptotic protein B-cell lymphoma 2 (Bcl-2) decreased, and the expression of pro-apoptotic proteins active Caspase 3 and $\mathrm{Bcl}-2$-associated $\mathrm{X}$ protein increased concurrently following aclidinium bromide stimulation using western blotting. The phosphorylation of protein kinase B and mechanistic target of rapamycin were significantly inhibited in MKN-28 cells treated with aclidinium bromide; and the activity of the downstream proteins such as p70S6K and Cyclin D1 were also significantly decreased. In conclusion, aclidinium bromide could inhibit gastric cancer cell proliferation and metastasis,
\end{abstract}

Correspondence to: Dr Ping Cui, Department of Oncology, Binzhou City TB Prevention and Control of Hospital, 108 Huancheng South Road, Huimin, Binzhou, Shandong 251700, P.R. China E-mail: cuipingbzjhyy@163.com

Key words: aclidinium bromide, gastric cancer, proliferation, invasion, migration, apoptosis, phosphatidylinositol-3-kinase which may be associated with the enhancement of apoptosis induced by the PI3K signaling pathway.

\section{Introduction}

Gastric cancer remains the leading cause of cancer deaths worldwide and adds a significant health burden in many high-risk areas of cancer, such as Eastern Asia (1). There are many treatments for gastric cancer, such as surgery, surgery combined with chemotherapy and radiotherapy. Even so, the survival rate and prognosis of gastric cancer patients are still poor (2).

Acting as a growth factor, acetylcholine (Ach) can stimulate cell growth in cholinergic autocrine loop $(3,4)$. Cancers derived from epithelial and endothelial cells can express a cholinergic autocrine loop (5-7). Therefore, Ach secreted by cancer or adjacent cells leads to stimulate tumor growth when it interacts with M3 muscarinic receptors, which were expressed on the cancer cells. Moreover, muscarinic receptors (M1 and M5) can also increase cell proliferation in majority of cancers derived from epithelial and endothelial cells $(6,8)$. Consistent with these, gastric cancer can express muscarinic receptors.

Aclidinium bromide, used for maintenance treatment of chronic obstructive pulmonary disease (COPD), is a long-acting inhalable muscarinic antagonist (9) and has a similar affinity for M1 to M5 muscarinic receptor subtypes (10). It has been reported that blockade of autocrine muscarinic cholinergic signaling with an M3 receptor antagonist or darifenacin might inhibit the growth of small cell lung cancer (SCLC) cells both in vitro and in vivo $(4,11)$. The ability of M3 antagonists to inhibit tumor progression also has been clearly demonstrated in colon cancer (12). Muscarinic agonists have been found to stimulate tumor growth in melanoma (13), pancreatic cancer (14), breast cancer (15), ovarian cancer (16) and prostate cancer (17). In contrast, muscarinic antagonists will also inhibit growth of these tumors. However, the role and mechanism of muscarinic antagonists in gastric cancer has not been extensively studied.

In this study, a series of in vitro experiments investigated the role of aclidinium bromide in gastric cancer MKN-28 cells and its mechanism, in order to provide new drugs and theoretical basis for the treatment of gastric cancer in the future. 


\section{Materials and methods}

Cell culture. Gastric cancer cell line MKN-28 and normal gastric mucosa GES-1 were purchased from Chinese Academy of Sciences Shanghai Branch cell bank. The cells were incubated in RPMI-1640 (HyClone; GE Healthcare Life Sciences, Logan, UT, USA) supplemented with $10 \%$ fetal bovine serum (FBS; Gibco; Thermo Fisher Scientific, Inc., Waltham, MA, USA), $100 \mathrm{U} / \mathrm{ml}$ penicillin and $0.1 \mathrm{mg} / \mathrm{ml}$ streptomycin at $37^{\circ} \mathrm{C}$ in a $5 \% \mathrm{CO}_{2}$ atmosphere. Until the cells grown to logarithmic phase, they were washed 3 times by PBS, digested with trypsin and then repeatedly beat to single cell suspension. The cells were then grown into a 6-well plate for subsequent experiments.

Western blot analysis. The treated cells were placed on ice to extract protein with RIPA lysis buffer (Beijing CWBIO Biotech Co., Ltd., Beijing, China) and heated at $95^{\circ} \mathrm{C}$ for 5 min. Protein concentration was detected using BCA Protein Assay kit (Beijing CWBIO Biotech Co., Ltd.). The cell lysates $(20 \mu \mathrm{g}$ protein/lane) were separated by SDS-PAGE and then transferred onto PVDF membranes. After blocked with $5 \%$ non-fat dry milk $1 \mathrm{~h}$, the membranes were then incubated with the following primary antibodies overnight at $4^{\circ} \mathrm{C}$ : AKT (1:1,000; Cell Signaling Technology, Inc., Danvers, MA, USA), p-AKT (1:1,000; Cell Signaling Technology, Inc.), mTor (1:1,000; Cell Signaling Technology, Inc.), p-mTor (1:1,000; Cell Signaling Technology, Inc.), p70S6K (PTG, 1:1,000), Bcl-2 (PTG, 1:1,000), active-Caspase3 (1:1,000; ProteinTech Group, Inc., Chicago, IL, USA), Cyclin D1 (1:1,000; ProteinTech Group, Inc.), GAPDH (1:5,000; ProteinTech Group, Inc.). After washing 3-5 min by TBST, secondary antibodies (Sigma-Aldrich; Merck KGaA, Darmstadt, Germany) were incubated at room temperature and developed by ECL (ProteinTech Group, Inc.) after washing membrane.

Quantity One was used to scan the gray scale values, and GAPDH was used as the internal control, and the target protein/internal reference was used to calculate the relative expression of each protein.

Cell proliferation assay. Cell Counting Kit-8 (CCK-8) assay was used to evaluate the growth of the cell lines according to the manufacturer's protocol. Cell suspension $(1,000$ cells/well $)$ were cultured in 96-well plates for $24 \mathrm{~h}$, then incubated with different concentrations of aclidinium bromide $(0,0.1,1,10$, 20,50 and $100 \mu \mathrm{M}$ ) and cultured for an additionally $72 \mathrm{~h}$. For CCK-8 detection, $10 \mu \mathrm{l}$ of CCK-8 solution was added into the wells and the cells were incubated at $37^{\circ} \mathrm{C}$ for $1.5 \mathrm{~h}$. The absorbance (optical density, OD) of cells was determined at $450 \mathrm{~nm}$ using a microplate reader (Bio-Rad Laboratories, Inc., Hercules, CA, USA). The following experiment drug concentration $(10 \mu \mathrm{M})$ was chosen from the series of the gradient concentration. Afterward, cells were incubated with $10 \mu \mathrm{M}$ aclidinium bromide and vehicle (DMSO, $0.1 \%$ in culture media) for $24,48,72 \mathrm{~h}$. Cells viabilities were measured by CCK- 8 assay and OD values were measured as above described.

Invasion and migration assay. Cell invasion was determined by using 24 -well transwell invasion chamber (EMD
Millipore, Billerica, MA, USA). A total of $100 \mu 1$ matrigel (BD Biosciences, Franklin Lakes, NJ, USA) were added to the upper chambers and stood $4-6 \mathrm{~h}$ at $37^{\circ} \mathrm{C}$ in a $\mathrm{CO}_{2}$ incubator. The lower chambers were filled with serum-free media and stood $0.5 \mathrm{~h}$ to hydrate basilar membrane. After incubation for $24 \mathrm{~h}$, cell suspension $\left(1 \times 10^{5}\right.$ cells $/ 100 \mu \mathrm{l}$ serum-free MEM media) were added to the upper chambers and complete culture solution (500 $\mu 1)$ were added to the lower chambers. To stay overnight, cells were washed in PBS, fixed for $30 \mathrm{~min}$ in $4 \%$ paraformaldehyde, stained for 20 min with $0.1 \%$ crystal violet. After the indicated treatments, five fields were randomly selected under the microscope and representative photographs of stained cells were taken to observation and count.

The migration assay was similar to the invasion assay, however, the transwell chamber was not required to use matrigel matrix and the number of cells would be 5,000.

Flow cytometry analysis of cell apoptosis. After the cells were treated for $24 \mathrm{~h}$, the medium was removed and replaced with serum-free medium to starvation for $24 \mathrm{~h}$ under normal conditions. Following the treatment, cells were trypsinized without EDTA and collected in a centrifuge tube, then the cells were centrifuged at $1,000 \mathrm{x} \mathrm{g}$ for $5 \mathrm{~min}$. Afterwards cells were resuspended in PBS pre-cooled at $4^{\circ} \mathrm{C}$, centrifuged again and carefully aspirated the supernatant. After that we added $1 \mathrm{X}$ binding buffer to resuspend the cells, and regulated the cell density of $1-5 \times 10^{6} / \mathrm{ml} .100 \mu \mathrm{l}$ of the cells were gently mixed with $5 \mu \mathrm{l}$ Annexin V-FITC/ PI (Beijing 4A Biotech Co., Ltd., Beijing, China) and incubated in the dark for $5 \mathrm{~min}$ at room temperature. $10 \mu 1$ of PI dye and $400 \mu 1$ of PBS were added to the sample, and the results were analyzed in a flow cytometer using Flowjo.

Statistical analysis. All statistical analyses were performed using SPSS 18.0 (SPSS, Inc., Chicago, IL, USA) software. The comparison between two groups were performed by Student's t-test and for $>2$ groups used analysis of variance followed by Dunnett's post hoc test. Data were expressed as mean \pm standard deviation, and the criteria for all statistical significances set as $\mathrm{P}<0.05$.

\section{Results}

Aclidinium bromide inhibits the proliferation of gastric cancer $M K N-28$ cells. CCK- 8 was conducted to investigate the effect of aclidinium bromide on the proliferation of gastric cancer cells. A dose response in proliferation was observed as a decrease in MKN-28 cells from 0.1 to $100 \mu \mathrm{M}$ of aclidinium bromide, while the proliferation of GES-1 cells was inhibited by aclidinium bromide beyond $50 \mu \mathrm{M}$ (Fig. 1A). Consequently, $10 \mu \mathrm{M}$ of aclidinium bromide was selected to perform following experiments. In addition, MKN-28 cells proliferation was assessed by measuring the OD values at increasing time-points. As shown in Fig. 1B, OD values of MKN-28 cells were decreased with a time-dependent manner. At 48 and $72 \mathrm{~h}$, the OD value was significant inhibited in aclidinium bromide treated group $(\mathrm{P}<0.01)$. These results suggested that aclidinium bromide impeded growth of gastric cancer cells.

Aclidinium bromide inhibits the invasion and migration of gastric cancer $M K N-28$ cells. To explore the effect of 

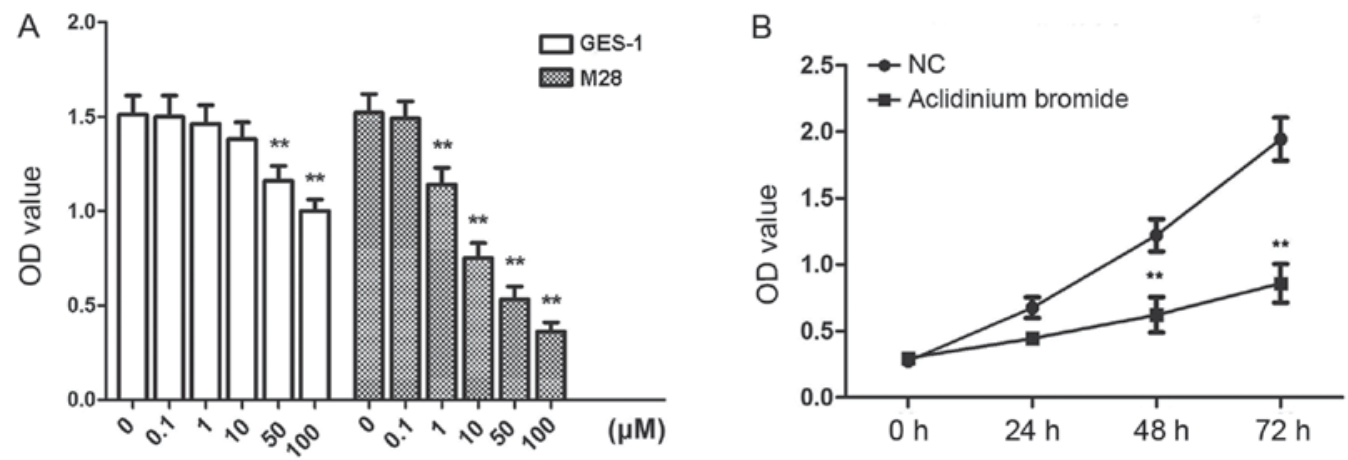

Figure 1. Suppressive effects of aclidinium bromide on gastric cancer MKN-28 cell proliferation. (A) The OD values of MKN-28 and GES-1 cells treated with aclidinium bromide at $0,0.1,1,10,50,100 \mu \mathrm{M} .{ }^{* *} \mathrm{P}<0.01$ vs. $0 \mu \mathrm{M}$ group. (B) The OD values of MKN-28 cells treated with aclidinium bromide following 0,24 , 48 and $72 \mathrm{~h} .{ }^{* *} \mathrm{P}<0.01$ vs. NC group. The data are presented as the mean \pm standard deviation. OD, optical density; NC, negative control; M28, MKN-28 cells.
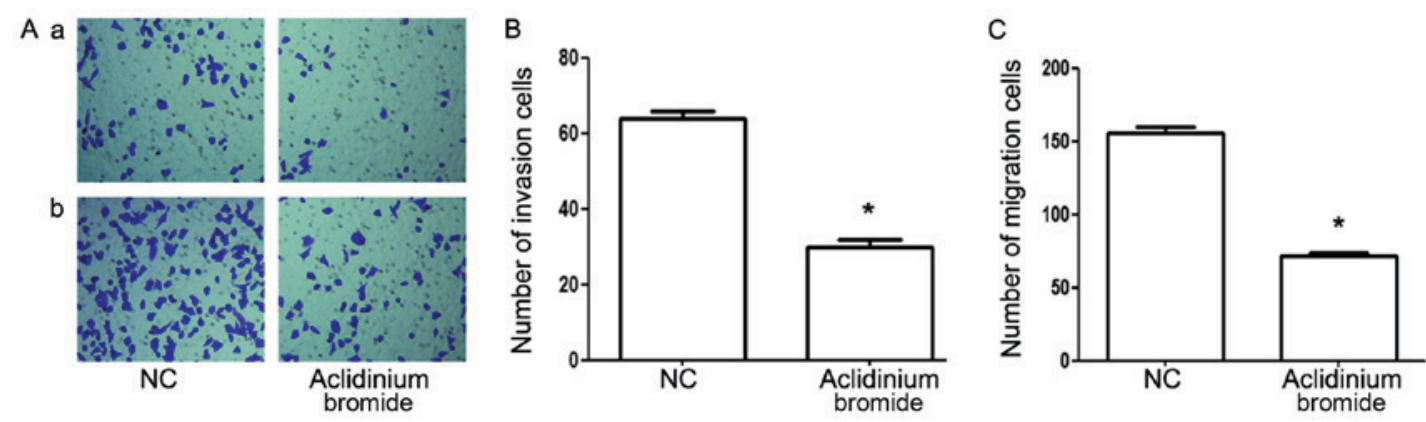

Figure 2. Aclidinium bromide inhibits the invasion and migration of gastric cancer MKN-28 cells. (Aa) Microscopic images of MKN-28 cells passing though the matrigel of the transwell chamber (invasion assay). (Ab) Microscopic images of MKN-28 cells passing though the microwells of the transwell chamber (migration assay; magnification, x100). Bar graphs presenting the number of (B) invading cells and (C) migrating cells. "P<0.05 vs. NC. Data are expressed as the mean \pm standard deviation. NC, negative control.

A

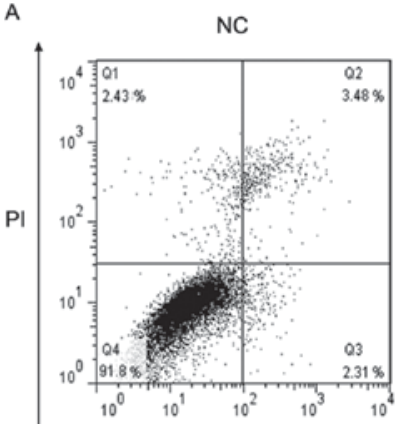

Annexin V FITC

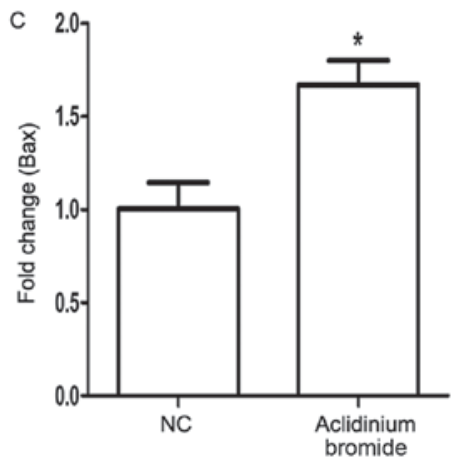

Aclidinium bromide

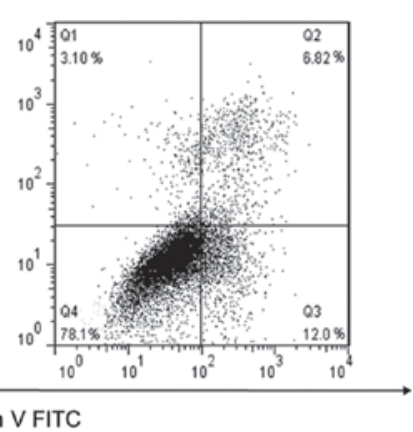

D

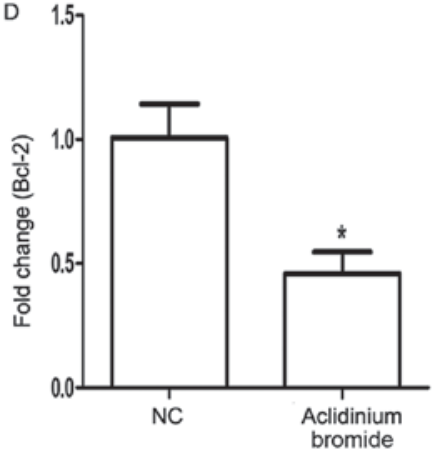

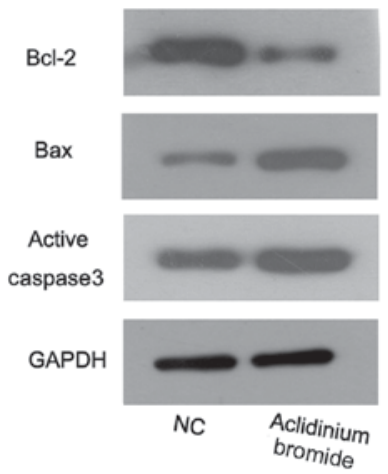

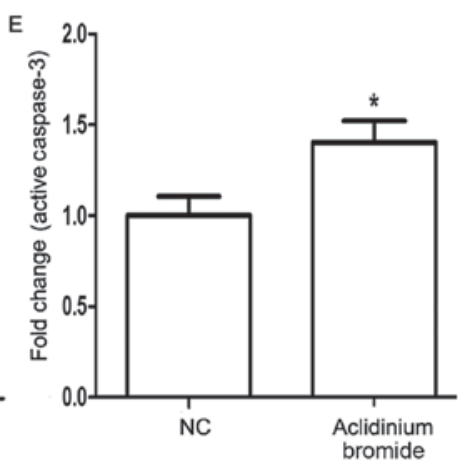

Figure 3. Aclidinium bromide induces the apoptosis of gastric cancer MKN-28 cells. (A) Flow cytometric plots showing the specific cell populations in MKN-28 cells. Q2 were late apoptotic cells, Q3 were live cells and Q4 were early apoptotic cells. (B) Expression of activated Bcl-2, Bax and active caspase3 were determined by western blotting. The expression levels of (C) Bax, (D) Bcl-2 and (E) active caspase 3 were determined following exposure to aclidinium bromide for $24 \mathrm{~h}$. Data were expressed as mean \pm standard deviation. ${ }^{*} \mathrm{P}<0.05$ vs. NC. NC, negative control; PI, propidium iodide; FITC, fluorescein isothiocyanate; Bcl-2, B-cell lymphoma 2; Bax, Bcl-2-associated X protein. 
A
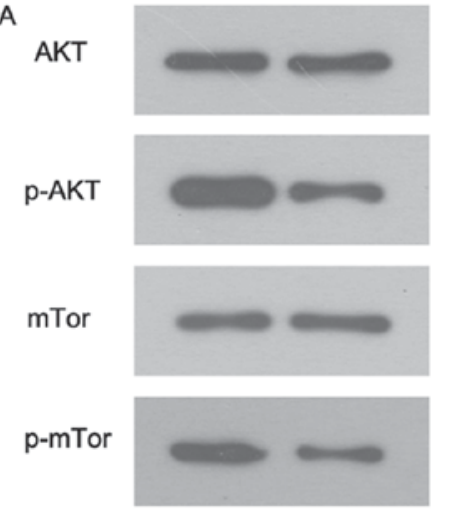

p70
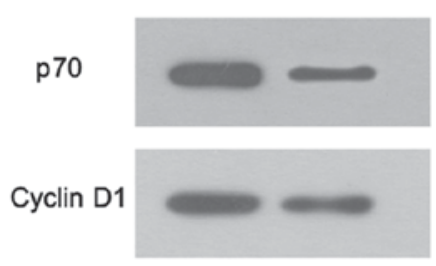

GAPDH

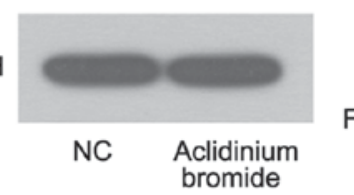

B

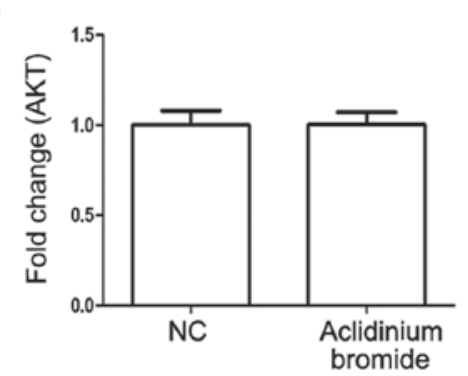

D
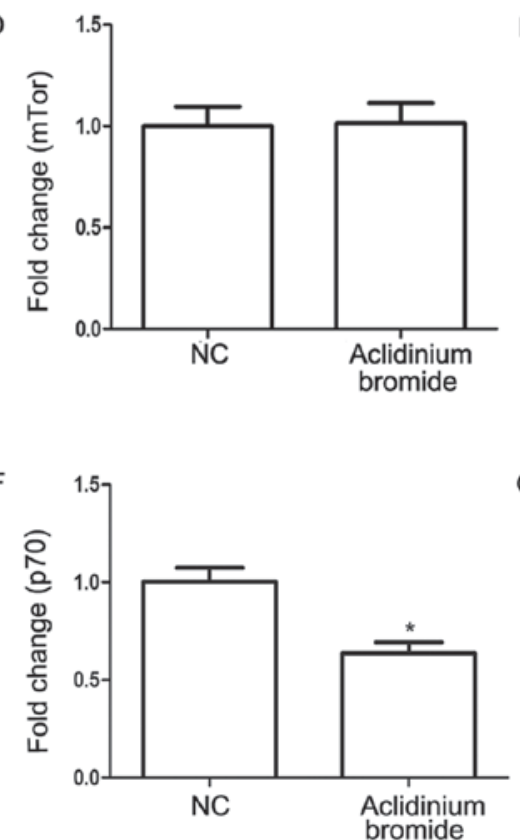

$\mathrm{C}$
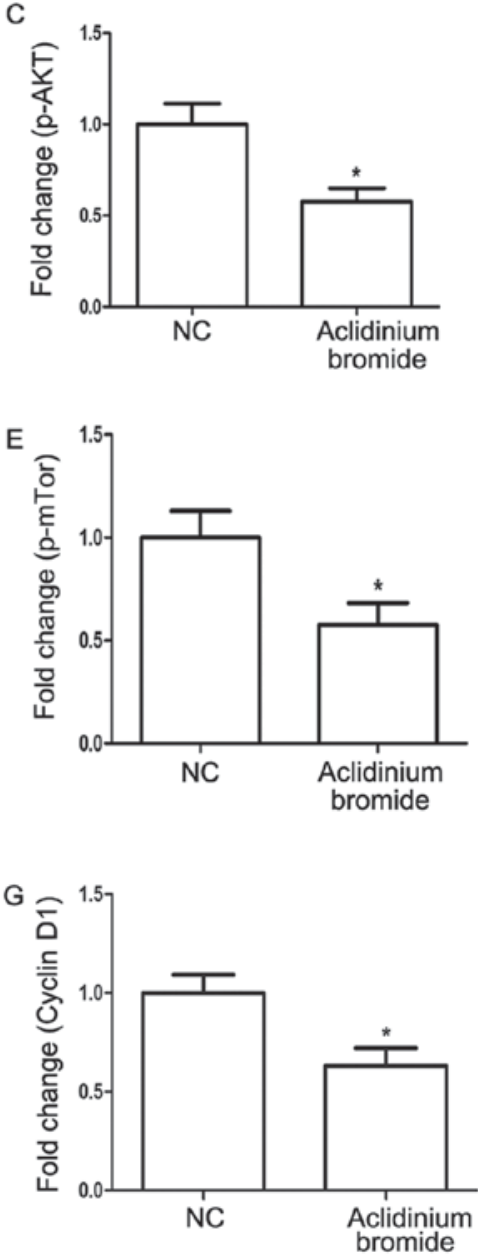

Figure 4. Aclidinium bromide inhibits the activation of the PI3K signaling pathway in gastric cancer MKN-28 cells. (A) Western blotting was performed to determine the expression of (B) AKT, (C) p-AKT, (D) mTor, (E) p-mTor, (F) p70S6K and (G) Cyclin D1. Data were expressed as the mean \pm standard deviation. ${ }^{*} \mathrm{P}<0.05$ vs. NC. NC, negative control; p-, phosphorylated; AKT, protein kinase B; mTor, mechanistic target of rapamycin.

aclidinium bromide on metastasis of gastric cancer MKN-28 cells, transwell assay and matrigel invasion assay were carried out. As shown in Fig. 2, matrigel invasion analysis showed the number of invasive cells were significantly decreased in aclidinium bromide treated group $(30 \pm 2)$ compared with that in the NC group $(64 \pm 2)(\mathrm{P}<0.05$; Fig. 2Aa and B). Furthermore, aclidinium bromide led to the remarkable reduction of the number of MKN-28 cells passing though the microwells of the transwell chamber $(156 \pm 4>72 \pm 2, \mathrm{P}<0.05$; Fig. $2 \mathrm{Ab}$ and $\mathrm{C})$. Collectively, the results showed that aclidinium bromide could significantly inhibit the invasion and migration potential of MKN-28 cells.

Aclidinium bromide induces apoptosis of gastric cancer $M K N-28$ cells. To explore whether the role of aclidinium bromide in MKN-28 cells was correlated with the apoptosis, flow cytometry after Annexin V-FITC/PI staining and western blot assay were used. The flow cytometry analysis showed that the apoptosis of cells treated with aclidinium bromide was significantly increased (18.82 $>5.79 \%, \mathrm{P}<0.05$, Fig. 3A). Next, we detected the expression of apoptosis-related protein Bcl-2, Bax, and Active Caspase 3 after aclidinium bromide treatment using western blotting (Fig. 3B). As expected, the expression levels of anti-apoptotic protein BCL-2 decreased ( $\mathrm{P}<0.05$; Fig. 3D), and the expression of pro-apoptotic protein Bax and Active Caspase 3 increased concurrently $(\mathrm{P}<0.05$; Fig. $3 \mathrm{C}$ and $\mathrm{E})$. Therefore, we considered that aclidinium bromide could induce the apoptosis of MKN-28 cell.

Aclidinium bromide inhibits the phosphatidylinositol-3-kinase (PI3K) signaling pathway in gastric cancer MKN-28 cells. PI3K/AKT/mTor signaling pathway is well-known pathway associated with cell proliferation, survival and metabolism. It is often activated in numerous types of tumors (18-20). In order to know whether the effect of aclidinium bromide on cells via the signaling pathway, we determined the effects of aclidinium bromide on activation of protein related with PI3K signaling pathway by western bolt assay (Fig. 4A). Accordingly, we found the phosphorylation of AKT and mTor were significantly inhibited in MKN-28 cells treated with aclidinium bromide (Fig. 4C and E, $\mathrm{P}<0.05)$. Besides, aclidinium bromide administration attenuated activity of the downstream proteins such as $\mathrm{p} 70$ ribosomal protein S6 kinase (p70S6K) and Cyclin D1 related to cell growth $(\mathrm{P}<0.05$; Fig. $4 \mathrm{~F}$ and $\mathrm{G})$. Therefore, aclidinium bromide inhibited the activation of PI3K signaling pathway in gastric cancer MKN-28 cells. 


\section{Discussion}

Recently, the ability of Ach and muscarinic receptors to regulate tumor cell proliferation has been significantly concerned (21). In this study we focused on the growth inhibitory effect of aclidinium bromide on gastric cancer cells and the possible mechanisms. In MKN-28 cells, aclidinium bromide displayed significant inhibited proliferation, invasion and migration ability. Next, we found aclidinium bromide could promote apoptosis. In addition, PI3K signaling pathway was also involved in the progression of gastric cancer cells, by which aclidinium bromide might inhibit the migration and proliferation of these cells.

A large number of studies have shown that many components of cholinergic signaling including Ach are present in a variety of non-neuronal tissues, such as lung cancer $(21,22)$, colon (23), breast, ovarian carcinomas $(24,25)$ and other common cancer cells. Interestingly, cholinergic signaling were found to increase further in the local tumor environment, representing a potential new pathway to target tumor growth (26). As can be seen, cholinergic antagonists may provide a directed pathway to prevent tumor proliferation by interrupting the upregulated autocrine signaling. As we found in MKN-28 cells that aclidinium bromide displayed significant inhibition of proliferation, invasion and migration activity. Cell cycle arrest is a major mechanism preventing tumor growth. Cesario et al (27) reported that inhibition of a7-nAChR with a powerful high affinity antagonist a-CbT induced antitumor activity in NSCLC and pleural mesothelioma by triggering apoptosis. Our results from flow cytometric analysis showed that aclidinium bromide markedly suppressed the expression of anti-apoptotic protein BCL-2 and increased the expression of pro-apoptotic protein BAX and Active Caspase3, which meant that aclidinium bromide could promote apoptotic of MKN-28 cells.

As a classical and important signaling pathway, PI3K/Akt is often activated in many human cancer types, and is thought to be associated with the characteristics of carcinogenesis, including cell proliferation, apoptosis and metabolism $(28,29)$. ACh can rapidly increases the amount of intracellular calcium in lung cancer cell lines, leading to the activation of M3 receptors, eventually resulting in activation of Akt and MAPK (19). Besides, this activation then inhibit cell proliferation by M3 antagonists. Coincidentally, we found that the phosphorylation of Akt and mTOR was significantly inhibited in MKN-28c ells treated with aclidinium bromide, so we believed aclidinium bromide inhibited the PI3K signaling pathway in gastric cancer MKN-28 cells. In this study, we also found that activity of p70S6K and Cyclin D1 was also inhibited and we identified they were the downstream targets of AKT that mediated acilidinium-inhibition. In summary, we found that PI3K signaling pathway may be involved in the aclidinium bromide-induced inhibition of MKN-28 cell proliferation, invasion and migration ability, meanwhile, the apoptosis of MKN-28 cells treated with aclidinium bromide may be achieved via the signaling pathway.

Unfortunately, given the limited experimental tools, we only select the MKN-28 cell line for the present study, and other gastric cancer cell lines should be further studied. Even so, we found that aclidinium bromide could inhibit proliferation, invasion and migration, and induce apoptosis in gastric cancer MKN-28 cells. In addition, we further demonstrated that aclidinium bromide caused the above effects via the PI3K signaling pathway. This novel finding provides a useful strategy for chemoprevention and/or treatment of gastric cancer. Next, we will conduct a series of in vivo experiments about this drug in patients with gastric cancer as an area of future research.

\section{Acknowledgements}

Not applicable.

\section{Funding}

No funding was received.

\section{Availability of data and materials}

The datasets used and/or analyzed during the current study are available from the corresponding author on reasonable request.

\section{Authors' contributions}

YZW contributed to the conception and design of the study and provided administrative support. PC and JJL contributed the study materials. JJL, HXW and JM performed data collection and assembly. HXW, PC and JM analyzed and interpreted the data. All authors contributed to the writing and editing of the manuscript, and all authors gave final approval of the manuscript.

\section{Ethics approval and consent to participate}

Not applicable.

\section{Consent for publication}

Not applicable.

\section{Competing interests}

The authors declare that they have no competing interests.

\section{References}

1. Torre LA, Bray F, Siegel RL, Ferlay J, Lortet-Tieulent J and Jemal A: Global cancer statistics, 2012. CA Cancer J Clin 65: 87-108, 2015

2. Lochhead P and El-Omar EM: Molecular predictors of gastric neoplastic progression. Cancer Cell 33: 9-11, 2018.

3. Cazzola M, Calzetta L, Page CP, Rogliani P, Facciolo F, Gavaldà A and Matera MG: Pharmacological characterization of the interaction between aclidinium bromide and formoterol fumarate on human isolated bronchi. Eur J Pharmacol 745: 135-143, 2014.

4. Ami N, Koga K, Fushiki H, Ueno Y, Ogino Y and Ohta H: Selective M3 muscarinic receptor antagonist inhibits small-cell lung carcinoma growth in a mouse orthotopic xenograft model. J Pharmacol Sci 116: 81-88, 2011.

5. Wang L, Zhi X, Zhang Q, Wei S, Li Z, Zhou J, Jiang J, Zhu Y, Yang L, Xu H and Xu Z: Muscarinic receptor M3 mediates cell proliferation induced by acetylcholine and contributes to apoptosis in gastric cancer. Tumour Biol 37: 2105-2117, 2016. 
6. Tang Y and Le W: Differential roles of M1 and M2 microglia in neurodegenerative diseases. Mol Neurobiol 53: 1181-1194, 2016.

7. Gentry PR, Kokubo M, Bridges TM, Cho HP, Smith E, Chase P, Hodder PS, Utley TJ, Rajapakse A, Byers F, et al: Discovery, synthesis and characterization of a highly muscarinic acetylcholine receptor (mAChR)-selective M5-orthosteric antagonist, VU0488130 (ML381): A novel molecular probe. ChemMedChem 9: 1677-1682, 2014.

8. Tully BT, Li M, Sun Y, Berkowitz J and Chai TC: Defects in muscarinic receptor cell signaling in bladder urothelial cancer cell lines. Urology 74: 467-473, 2009.

9. Bateman ED, Chapman KR, Singh D, D'Urzo AD, Molins E, Leselbaum A and Gil EG: Aclidinium bromide and formoterol fumarate as a fixed-dose combination in COPD: Pooled analysis of symptoms and exacerbations from two six-month, multicentre, randomised studies (ACLIFORM and AUGMENT). Respir Res 16: 92, 2015

10. Melani AS: Long-acting muscarinic antagonists. Expert Rev Clin Pharmacol 8: 479-501, 2015.

11. von Rosenvinge EC, Cheng K, Drachenberg CB, Fowler CB Evers DL, Xie G and Raufman JP: Bedside to bench: role of muscarinic receptor activation in ultrarapid growth of colorectal cancer in a patient with pheochromocytoma. Mayo Clin Proc 88 1340-1346, 2013.

12. Xu ZP, Song Y, Yang K, Zhou W, Hou LN, Zhu L, Chen HZ and Cui YY: M3 mAChR-mediated IL-8 expression through $\mathrm{PKC/NF- \kappa B} \mathrm{signaling} \mathrm{pathways.} \mathrm{Inflamm} \mathrm{Res} \mathrm{63:} \mathrm{463-473,} 2014$

13. Spindel ER: Muscarinic receptor agonists and antagonists: Effects on cancer. Handb Exp Pharmacol: 451-468, 2012.

14. Ehlert FJ, Pak KJ and Griffin MT: Muscarinic agonists and antagonists: Effects on gastrointestinal function. Handb Exp Pharmacol: 343-374, 2012 .

15. Lombardi MG, Negroni MP, Pelegrina LT, Castro ME, Fiszman GL, Azar ME, Morgado CC and Sales ME: Autoantibodies against muscarinic receptors in breast cancer: Their role in tumor angiogenesis. PLoS One 8: e57572, 2013.

16. Trkulja V, Crljen-Manestar V, Banfic H and Lackovic Z: Involvement of the peripheral cholinergic muscarinic system in the compensatory ovarian hypertrophy in the rat. Exp Biol Med (Maywood) 229: 793-805, 2004.

17. Pagès G, Durivault J, Hannoun-Levi JM, Viera A and Ortholan C: 45 POSTER VEGF targeting increases the cystostatic effect of docetaxel on prostate and breast tumor cells; a new interpretation of the therapeutic effect. Eur J Cancer Supplements 6: 18, 2008.

18. Li D, Wei X, Ma M, Jia H, Zhang Y, Kang W, Wang T and Shi X FFJ-3 inhibits PKM2 protein expression via the PI3K/Akt signaling pathway and activates the mitochondrial apoptosis signaling pathway in human cancer cells. Oncol Lett 13: 2607-2614, 2017.
19. Xu R, Shang C, Zhao J, Han Y, Liu J, Chen K and Shi W: Activation of M3 muscarinic receptor by acetylcholine promotes non-small cell lung cancer cell proliferation and invasion via EGFR/PI3K/AKT pathway. Tumour Biol 36: 4091-4100, 2015.

20. Zhang X, Shi H, Tang H, Fang Z, Wang J and Cui S: miR-218 inhibits the invasion and migration of colon cancer cells by targeting the PI3K/Akt/mTOR signaling pathway. Int J Mol Med 35: 1301-1308, 2015.

21. Arrighi N, Bodei S, Zani D, Michel MC, Simeone C, Cosciani Cunico S, Spano P and Sigala S: Different muscarinic receptor subtypes modulate proliferation of primary human detrusor smooth muscle cells via Akt/PI3K and map kinases. Pharmacol Res 74: 1-6, 2013.

22. Cabadak H, Aydin B and Kan B: Regulation of M2, M3, and M4 muscarinic receptor expression in K562 chronic myelogenous leukemic cells by carbachol. J Recept Signal Transduct Res 31: 26-32, 2011

23. Raufman JP, Cheng K, Saxena N, Chahdi A, Belo A, Khurana S and Xie G: Muscarinic receptor agonists stimulate matrix metalloproteinase 1-dependent invasion of human colon cancer cells. Biochem Biophys Res Commun 415: 319-324, 2011.

24. Parnell EA, Calleja-Macias IE, Kalantari M, Grando SA and Bernard HU: Muscarinic cholinergic signaling in cervical cancer cells affects cell motility via ERK1/2 signaling. Life Sci 91: 1093-1098, 2012

25. Xu Y, Wang S, Chan HF, Lu H, Lin Z, He C and Chen M: Dihydromyricetin induces apoptosis and reverses drug resistance in ovarian cancer cells by p53-mediated downregulation of survivin. Sci Rep 7: 46060, 2017.

26. Zhao Q, Gu X, Zhang C, Lu Q, Chen H and Xu L: Blocking M2 muscarinic receptor signaling inhibits tumor growth and reverses epithelial-mesenchymal transition (EMT) in non-small cell lung cancer (NSCLC). Cancer Biol Ther 16: 634-643, 2015.

27. Cesario A, Russo P, Nastrucci C and Granone P: Is $\alpha 7-n A C h R$ a possible target for lung cancer and malignant pleural mesothelioma treatment? Current drug targets 13: 688-694, 2012.

28. Zhao R, Chen M, Jiang Z, Zhao F, Xi B, Zhang X, Fu H and Zhou K: Platycodin-D induced autophagy in non-small cell lung cancer cells via PI3K/Akt/mTOR and MAPK signaling pathways. J Cancer 6: 623-631, 2015.

29. Yuan L, Wei S, Wang J and Liu X: Isoorientin induces apoptosis and autophagy simultaneously by reactive oxygen species (ROS)-related p53, PI3K/Akt, JNK, and p38 signalin pathways in HepG2 cancer cells. J Agric Food Chem 62: 5390-5400, 2014. 